\title{
A Study on Extent of Use of Drip Irrigation System by Sugarcane Farmers in Telangana State, India
}

\author{
M. Swetha*, V. Sudha Rani, I. Sreenivasa Rao and K.B. Suneetha Devi
}

Department of Agricultural Extension, College of Agriculture, PJTSAU, Rajendranagar, Hyd-30, Telangana, India

*Corresponding author

\section{A B S T R A C T}

Keywords

Extent of use, Sugarcane, Drip, Drip irrigation in sugarcane etc.

Article Info

Accepted:

14 September 2017

Available Online:

10 October 2017
Sugarcane Farming is one of the important segments of Indian agriculture because it is raw material to sugar industry for which India ranks second in the world economy. Under the depleting groundwater scenario, productivity of high water requiring crops like sugarcane can only be sustained using water-economizing techniques like drip irrigation. The study was carried out to assess the extent of use of drip irrigation system in sugarcane crop. For this purpose, 240 sugarcane growers in three districts Telangana state were taken as study respondents. This paper has made an attempt to reveal the extent of use of drip irrigation system by sugarcane farmers. The study revealed that 32.50 per cent of the sugarcane drip farmers fell under the category of low extent of use followed by medium, high extent of use, very high and very low extent of use respectively.

\section{Introduction}

Drip irrigation is an efficient method of providing irrigation water directly into soil at the root zone of plants and thus, minimizes conventional losses such as deep percolation, runoff and soil erosion. Unlike surface irrigation, drip irrigation is more suitable and economical if it is introduced in water scarce areas having undulated topography, shallow and sandy soils and for wide spaced high value crops. It also permits the utilization of fertilizers, pesticides and other water-soluble chemicals along with irrigation water resulting in higher yields and better quality produce. Hence, drip irrigation system is regarded as panacea for many of the problems in dry land agriculture and improving the efficiency in irrigated agriculture. Apart from being a water intensive crop, sugarcane has been cultivated mainly under surface method of irrigation, where water use efficiency is very low (35-40 per cent) owing to substantial evaporation and distribution losses (Sivanappan, 1994). Unlike surface method of irrigation, under drip method of irrigation, water is supplied directly to the root zone of the crops through a network of pipes, which saves enormous amount of water by reducing evaporation and distribution losses. This method is rapidly gaining importance in the area where water is scare and high value crops are produced. Accordingly Telangana Micro Irrigation project (TSMIP) was carved 
out of AP Micro Irrigation Project. Drip irrigation technology requires relatively higher amount of fixed capital and therefore, farmers are getting subsidy from TSMIP. In several cases, even after the adoption of drip irrigation, the farmers discontinued drip irrigation due to lack of maintenance, irrelevant cultural background and unreliable water supply (Kulecho and Weatherhead, 2005). This paper has made an attempt to study the extent of use of drip irrigation system in sugarcane crop.

\section{Materials and Methods}

List of operations in drip irrigation system maintenance practices were prepared. These were divided into two groups as operations to be done before and at the time of installation of drip system and operations to be done frequently in drip irrigation system. 9 operations were listed with Yes and No response categories for the operations to be done before and at the time of installation and 18 operations were listed with frequently, seldom and never response categories for the operations to be done frequently in drip irrigation system. Total 27 operations were listed to elicit the response on extent of use of drip irrigation system in sugarcane crop. A score of ' 1 ' and ' 0 ' was assigned to Yes or No responses respectively for the set of 9 statements in operations to be done before and at the time of installation of drip irrigation system. A score of ' 2 ', ' 1 ' and ' 0 ' was assigned to frequently, seldom and never responses respectively for the set of 18 statements in operations to be done frequently in drip irrigation system. Combined score of two sets were taken for the score of each respondent total score for extent of use.

\section{Results and Discussion}

The results in the Table 1 and Figure 1 indicated that, 32.50 per cent of the sugarcane drip farmers fell under the category of low extent of use followed by medium (27.08\%), high extent of use $(18.33 \%)$, very high $(11.67 \%)$ and very low extent of use $(7.08 \%)$ respectively.

The low extent of use of drip irrigation system by sugarcane farmers could be due to medium to low level of information management behaviour, medium knowledge, less number of trainings undergone, medium to low level of innovativeness. Sugarcane is being a perennial crop the acid treatment cannot be done during the crop period because of crop damage. The acids which are used for the shock treatment of drip irrigation system were not easily available in the market.

Table.1 Distribution of the sugarcane drip farmers according to the extent of use of drip irrigation system in sugarcane crop $\mathrm{N}=240$

\begin{tabular}{|l|l|c|c|}
\hline S.No. & Category & Frequency & Percentage \\
\hline 1 & Very low & 17 & 7.08 \\
\hline 2 & Low & 78 & 32.50 \\
\hline 3 & Medium & 65 & 27.08 \\
\hline 4 & High & 44 & 18.33 \\
\hline 5 & Very high & 28 & 11.67 \\
\hline
\end{tabular}


Table.2 Extent of adoption of maintenance practices in drip irrigation System by sugarcane farmer

\begin{tabular}{|c|c|c|c|c|c|c|c|}
\hline S. No. & $\begin{array}{l}\text { Operations to be done at once before and } \\
\text { at the time of installation of drip system }\end{array}$ & YES & \multicolumn{2}{|l|}{ NO } & T.S & M.S & Rank \\
\hline 1 & $\begin{array}{l}\text { Soil properties, water quality should be } \\
\text { checked }\end{array}$ & 184 & \multicolumn{2}{|l|}{56} & 184 & 0.77 & $\mathbf{V}$ \\
\hline 2 & Levelling of the land should be done & 220 & \multicolumn{2}{|l|}{20} & 220 & 0.91 & II \\
\hline 3 & $\begin{array}{l}\text { For paired row system spacing of the laterals } \\
\text { should be } 6 \text { feet to } 8 \text { feet }\end{array}$ & 85 & \multicolumn{2}{|l|}{155} & 85 & 0.35 & VIII \\
\hline 4 & $\begin{array}{l}\text { In paired row planting method one lateral } \\
\text { should be placed between two adjacent rows } \\
\text { of cane }\end{array}$ & 80 & \multicolumn{2}{|l|}{160} & 80 & 0.33 & IX \\
\hline 5 & $\begin{array}{l}\text { Spacing of the drippers is } 40 \text { to } 90 \mathrm{~cm} \\
\text { depending on the soil type }\end{array}$ & 196 & \multicolumn{2}{|l|}{44} & 196 & 0.82 & IV \\
\hline 6 & $\begin{array}{l}\text { Installation of the drip should be as per } \\
\text { accurate design }\end{array}$ & 212 & \multicolumn{2}{|l|}{28} & 212 & 0.88 & III \\
\hline 7 & $\begin{array}{l}\text { Operate the drip system } 12-24 \text { hours for to } \\
\text { bring soil moisture at field capacity at the } \\
\text { time of planting }\end{array}$ & 223 & \multicolumn{2}{|l|}{27} & 223 & 0.93 & I \\
\hline 8 & $\begin{array}{l}\text { System should be flushed before start of the } \\
\text { crop }\end{array}$ & 168 & \multicolumn{2}{|l|}{72} & 168 & 0.70 & VI \\
\hline 9 & $\begin{array}{l}\text { In sand filter level of sand should be } \\
\text { maintained }\end{array}$ & 150 & \multicolumn{2}{|l|}{90} & 150 & 0.62 & VII \\
\hline \multicolumn{2}{|c|}{$\begin{array}{l}\text { Operations to be done frequently in drip irrigation } \\
\text { system }\end{array}$} & Frequent & Seldom & Never & T.S & M.S & Rank \\
\hline 10 & $\begin{array}{l}\text { Regular back flush of the sand filter (*once } \\
\text { in a day) }\end{array}$ & 65 & 160 & 15 & 290 & 1.2 & VIII \\
\hline 11 & $\begin{array}{l}\text { Change/ rectify the media if the media is } \\
\text { getting rounded off in the sand filter }\end{array}$ & 7 & 33 & 200 & 47 & 0.2 & XVI \\
\hline 12 & $\begin{array}{l}\text { In case of screen filters checking the filter } \\
\text { element and gasket closely }\end{array}$ & 89 & 113 & 38 & 291 & 1.21 & VII \\
\hline 13 & $\begin{array}{l}\text { The system should always be flushed after } \\
\text { any repairs }\end{array}$ & 120 & 86 & 34 & 326 & 1.36 & VI \\
\hline 14 & Check the pressure gauges and ventury & 106 & 79 & 55 & 291 & 1.21 & VII \\
\hline 15 & $\begin{array}{l}\text { Wash the filter elements before starting } \\
\text { fertigation }\end{array}$ & 84 & 98 & 58 & 266 & 1.11 & $\mathbf{X}$ \\
\hline 16 & Flush the laterals weekly/ fortnightly & 186 & 45 & 9 & 417 & 1.74 & II \\
\hline 17 & $\begin{array}{l}\text { Fertigation should be done in the middle of } \\
\text { an irrigation event }\end{array}$ & 165 & 68 & 17 & 398 & 1.66 & IV \\
\hline 18 & $\begin{array}{l}\text { After the completion of the fertigation, } \\
\text { irrigation should be continued for another } 15 \\
\text { minutes }\end{array}$ & 154 & 75 & 21 & 383 & 1.59 & $\mathbf{V}$ \\
\hline 19 & $\begin{array}{l}\text { Concentration of the fertilizers in effective } \\
\text { root zone should not exceed } 1000 \mathrm{ppm}\end{array}$ & 25 & 63 & 152 & 113 & 0.47 & XIII \\
\hline 20 & Acid treatment with chlorine $10-20 \mathrm{ppm}$ & 11 & 38 & 191 & 60 & 0.25 & $\mathbf{X V}$ \\
\hline 21 & $\begin{array}{l}\text { Inject the acid and keep it for } 30-60 \text { minutes } \\
\text { once in } 3 \text { months for acid treatment }\end{array}$ & 10 & 45 & 185 & 65 & 0.27 & XIV \\
\hline 22 & $\begin{array}{l}\text { Shut the system for } 24 \text { hours during acid } \\
\text { treatment }\end{array}$ & 12 & 35 & 193 & 59 & 0.25 & $\mathbf{X V}$ \\
\hline 23 & $\begin{array}{l}\text { Flush all the sub mains and laterals after } \\
\text { acid treatment }\end{array}$ & 48 & 95 & 97 & 191 & 0.79 & $\mathbf{X I}$ \\
\hline 24 & Rodents and pest should be controlled & 112 & 52 & 76 & 276 & 1.15 & IX \\
\hline 25 & $\begin{array}{l}\text { Clogged emitters should be cleaned and if } \\
\text { not working, should be replaced }\end{array}$ & 196 & 34 & 10 & 426 & 1.77 & $\mathbf{I}$ \\
\hline 26 & Care should be taken to prevent leakage & 175 & 63 & 2 & 413 & 1.72 & III \\
\hline 27 & $\begin{array}{l}\text { Regular checking of valves and pressure } \\
\text { guage for uniform irrigation }\end{array}$ & 163 & 71 & 7 & 142 & 0.59 & XII \\
\hline
\end{tabular}


Fig.1 Distribution of the respondents according to their extent of use of drip irrigation system in sugarcane crop $\mathrm{N}=240$

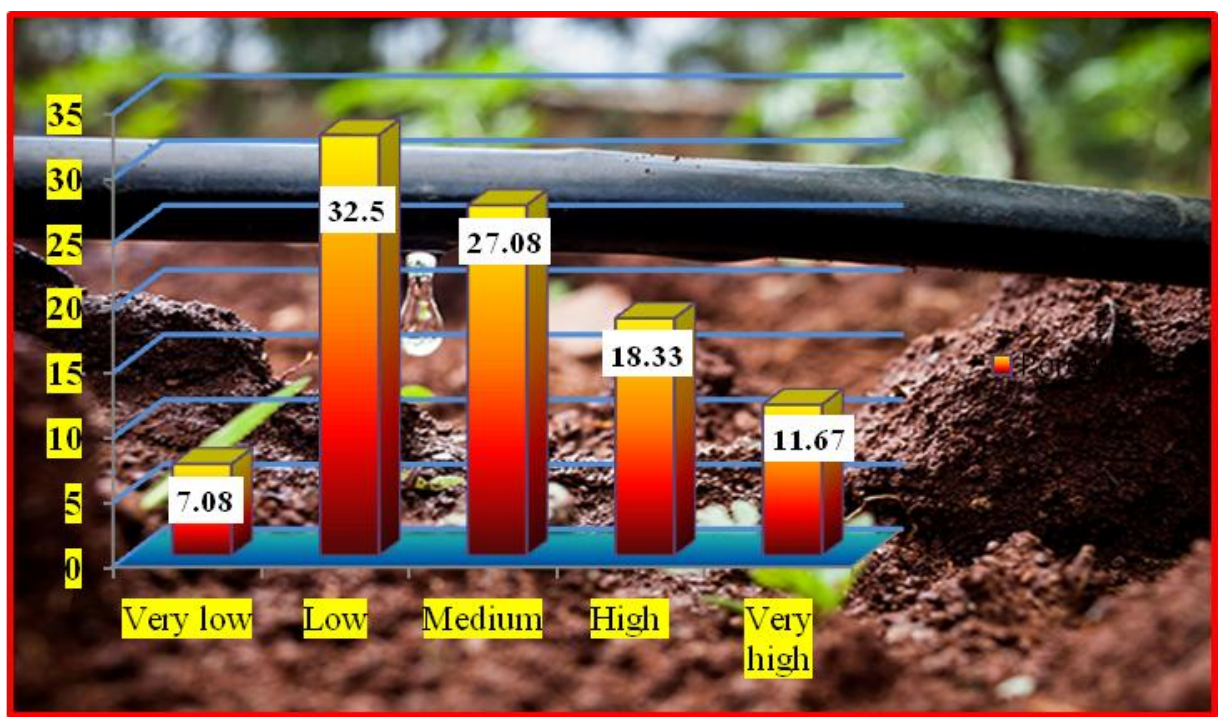

The important problem of farmers i.e. availability of groundwater for irrigation purpose was overcome by drip irrigation system as they can irrigate additional area with available water by adopting drip irrigation system; the farmers were satisfied with this feature and they were not taking care about maintenance of system. Lack of proper knowledge on operation and maintenance of drip irrigation system, poor after sales services by MI company employees, lack of availability of spare parts and chemicals for cleaning of drip irrigation system might be the reason for low extent of drip irrigation system use. The results are in conformity with the findings of Katkar and Milind (2006).

Further, the rank wise analysis (Table 2) of extent of adoption of various maintenance practices in drip irrigation system by sugarcane farmers indicate that In the operations to be done before and at the time installation of the drip irrigation system the first rank was obtained on the operation of operate the drip system 12-24 hours for to bring soil moisture at field capacity at the time of planting followed by levelling of the land should be done, installation of the drip should be as per accurate design, spacing of the drippers is 40 to $90 \mathrm{~cm}$ depending on the soil type, soil properties, water quality should be checked, system should be flushed before start of the crop, in sand filter level of sand should be maintained, for paired row system spacing of the laterals should be 6 feet to 8 feet and in paired row planting method one lateral should be placed between two adjacent rows of cane. In operations to be done after installation of drip irrigation by sugarcane farmers the first rank was obtained on the operation of clogged emitters should be cleaned and if not working, should be replaced, flush the laterals weekly/ fortnightly, care should be taken to prevent leakage, fertigation should be done in the middle of an irrigation event, after the completion of the fertigation, irrigation should be continued for another 15 minutes, the system should always be flushed after any repairs, check the pressure gauges and ventury, in case of screen filters checking the filter element and gasket closely, regular back flush of the sand filter (*once in a day), rodents and pest should be controlled, wash the filter elements before starting fertigation, flush all the sub mains and laterals after acid 
treatment, concentration of the fertilizers in effective root zone should not exceed 1000 ppm, inject the acid and keep it for 30-60 minutes once in 3 months for acid treatment, shut the system for 24 hours during acid treatment and change/ rectify the media if the media is getting rounded off in the sand filter.

Most of the sugarcane farmers were under the category of low extent of use of drip irrigation system. Most of the sugarcane farmers adopting the practice of operating the drip system 12-24 hours for to bring soil moisture at field capacity at the time of planting before and at the time of installation and clogged emitters should be cleaned and if not working after installation.

\section{References}

Digrase, L.N., Sondge V D and Sawant B P. 2004. Optimization of irrigation water and fertilizer use for seasonal sugarcane (CO-7714) through drip irrigation system on vertisols. Journal of Soils and Crops. 14: 273-277.

Friedlander, L., Tal A and Lazarovitch N. 2013. Technical considerations affecting adoption of drip irrigation in sub-Saharan Africa. Agricultural Water Management. 126: 125- 132.

Katkar, B.S., and Milind C A. 2006. A study on adoption of drip irrigation system in Maharashtra State. International Journal of agricultural Sciences. 2 (2): 335-337.

Kulecho, I.K., and Weatherhead E K. 2005. Reasons for smallholder farmers discontinuing with low cost micro irrigation: A case study from Kenya. Irrigation and Drainage Systems. 19: 179-188.

Sivanappan, R.K., 1994. Prospects of microirrigation in India. Irrigation and Drainage System. 8: 49-58.

\section{How to cite this article:}

Swetha, M., V. Sudha Rani, I. Sreenivasa Rao and Suneetha Devi, K.B. 2017. A Study on Extent of Use of Drip Irrigation System by Sugarcane Farmers in Telangana State, India. Int.J.Curr.Microbiol.App.Sci. 6(10): 1643-1647. doi: https://doi.org/10.20546/ijcmas.2017.610.198 